ҚАЗАҚСТАН РЕСПУБЛИКАСЫ

ҰЛТТЫҚ ҒЫЛЫМ АКАДЕМИЯСЫНЫҢ

Абай атындағы Қазақ ұлттық педагогикалық университетінің
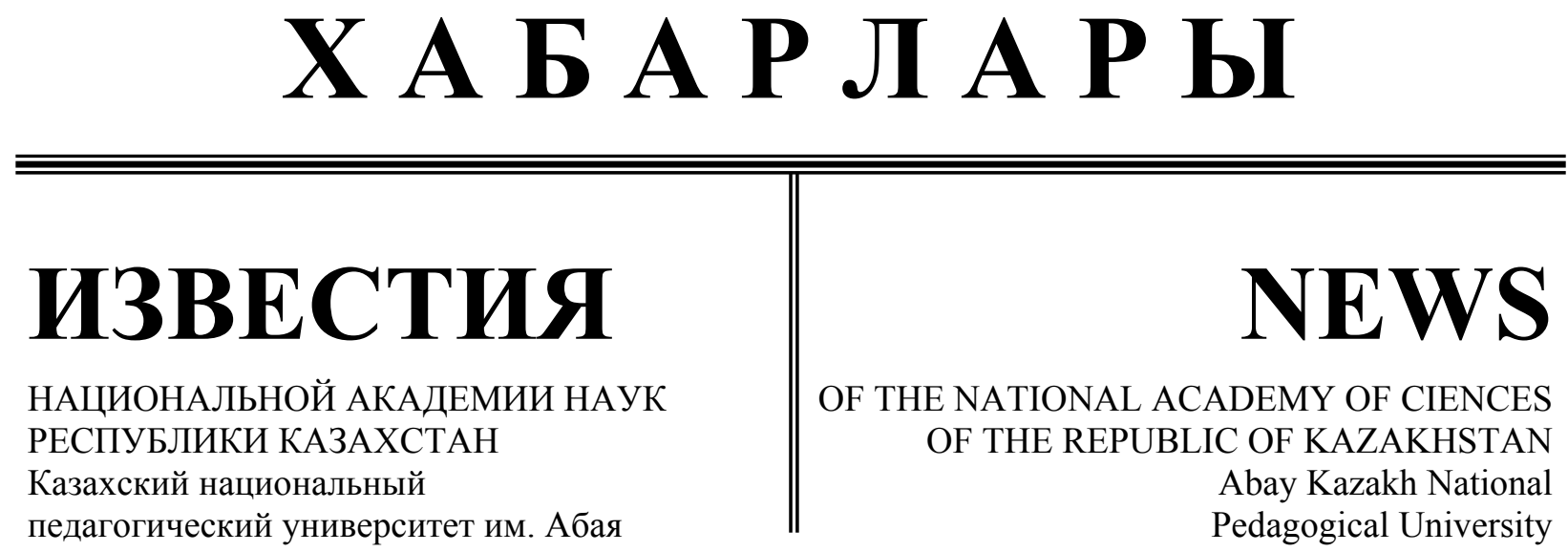

\author{
SERIES \\ OF SOCIAL AND HUMAN SCIENCES
}

2 (330)

MARCH - APRIL 2020

PUBLISHED SINCE JANUARY 1962

PUBLISHED 6 TIMES A YEAR 
Бас редактор

ҚР ҰҒА құрметті мүшесі

Балықбаев Т.O.

Р ед акция а лқ а сы:

экон. ғ. докторы, проф., ҚР ҰҒА академигі Баймұратов У.Б.; филос. ғ.докторы, проф., ҚР ҰҒА академигі Есім Г.Е.; фил. ғ. докторы,, проф., ҚР ҰҒА академигі Қирабаев С.С.; эк. ғ. докторы, проф., ҚР ҰҒА академигі Қошанов А.К.; эк.ғ. докторы, проф., ҚР ҰҒА академигі Нәрібаев К.Н. (бас редактордың орынбасары); филос. ғ.докторы, проф., ҚР ҰҒА академигі Нысанбаев А.Н.; заң ғ. докторы, проф., ҚР ҰҒА академигі Сәбікенов С.Н.; заң ғ. докторы, проф., ҚР ҰҒА академигі Сүлейменов М.К.; эк. ғ. докторы, проф., ҚР ҰҒА академигі Сатыбалдин С.С.; тарих ғ. докторы, проф., ҚР ҰҒА академик Әбжанов Х.М.; тарих ғ. докторы, проф., ҚР ҰҒА корр. мүшесі Әбусеитова М.Х.; тарих ғ. докторы, проф., ҚР ҰҒА академик Байтанаев Б.А.; филол. Ғ. докторы, проф., ҚР ҰҒА корр. мүшесі Жақып Б.А.; фил. ғ. докторы, проф., академик НАН РК Қалижанов У.К.; филол. ғ. докторы, проф., ҚР ҰҒА академик Қамзабекұлы Д.; тарих ғ. докторы, проф., ҚР ҰҒА академик Қожамжарова Д.П.; тарих ғ. док-торы, проф., ҚР ҰҒА академик Қойгелдиев М.К.; фил. ғ. докторы, проф., ҚР ҰҒА корр. мүшесі Құрманбайұлы Ш.; тарих ғ. докторы, проф., ҚР ҰҒА корр. мүшесі Таймағанбетов Ж.К.; социол. ғ. докторы, проф., ҚР ҰҒА корр. мүшесі Шәукенова 3.К.; фил. ғ. докторы, проф., ҚР ҰҒА корр. мүшесі Дербісәлі А.; саяси. ғ. докторы, проф., Бижанов А.К., тарих ғ. докторы, проф., Кабульдинов 3.Е.; фил. ғ. докторы, проф., ҚР ҰҒА корр мүшесі Қажыбек Е.3.

Р еда ц ия ке н е с і:

Молдова Республикасының ҰҒА академигі Белостечник Г. (Молдова); Әзірбайжан ҰҒА академигі Велиханлы Н. (Азербайджан); Тәжікстан ҰҒА академигі Назаров Т.Н. (Тәжікстан); Молдова Республикасының ҰҒА академигі Рошка А. (Молдова); Молдова Республикасының ҰҒА академигі Руснак Г. (Молдова); Әзірбайжан ҰҒА корр. мүшесі Мурадов Ш. (Әзірбайжан); Әзірбайжан ҰҒА корр. мүшесі Сафарова 3. (Әзірбайжан); э. ғ. д., проф. Василенко В.Н. (Украина); заң ғ. докт., проф. Устименко В.А. (Украина)

«Қазақстан Республикасы Ұлттық ғылым академиясының Хабарлары. Қоғамдық және гуманитарлық ғылымдар сериясы».

ISSN 2224-5294

Меншіктенуші: «Қазақстан Республикасының Ұлттық ғылым академиясы» РҚБ (Алматы қ.)

Қазақстан республикасының Мәдениет пен ақпарат министрлігінің Ақпарат және мұрағат комитетінде 30.04.2010 ж. берілген № 10894-Ж мерзімдік басылым тіркеуіне қойылу туралы куәлік

Мерзімділігі: жылына 6 рет.

Тиражы: 500 дана.

Редакцияның мекенжайы: 050010, Алматы қ., Шевченко көш., 28; 219, 220 бөл.; тел.: 272-13-19, 272-13-18 http://soc-human.kz/index.php/en/arhiv

(C) Қазақстан Республикасының Ұлттық ғылым академиясы, 2020

Типографияның мекенжайы: «NurNaz GRACE», Алматы қ., Рысқұлов көш., 103. 
Главный редактор

Почетный член НАН РК

T.O. Балыкбаев

Р едакционнная коллегия:

докт. экон. Н., проф., академик НАН РК У.Б. Баймуратов; докт. филос. н., проф., академик НАН РК Г.Е. Есим; докт. фил. Н., проф., академик НАН РК С.С. Кирабаев; докт. экон. Н., проф., академик НАН РК А.К. Кошанов; докт. экон. Н., проф., академик НАН РК К.Н. Нарибаев (заместитель главного редактора); докт. филос. н., проф., академик НАН РК А.Н. Нысанбаев; докт. юр. Н., проф., академик НАН РК С.Н. Саби-кенов; докт. юр. Н., проф., академик НАН РК М.К. Сулейменов; докт. экон. Н., проф., академик НАН РК С.С. Сатубалдин; докт. ист. н., проф., академик НАН РК Х.М. Абжанов; докт. ист. н., проф., чл.-корр. НАН РК М.Х. Абусеитова; докт. ист. Н., проф., академик НАН РК Б.А. Бай-танаев; докт. фил. н., проф., чл.-корр. НАН РК Б.А. Жакып; докт. фиолол. н., проф., академик НАН РК У.К. Калижанов; докт. фил. н., проф., академик НАН РК Д. Камзабекулы; докт. ист. н., проф., академик НАН РК Д.П. Кожамжарова; докт. ист. Н., проф., академик НАН РК М.К. Кой-гельдиев; докт. филол. н., проф., чл.-корр. НАН РК Ш. Курманбайулы; докт. ист. Н., проф., чл.-корр. НАН РК Ж.К. Таймаганбетов; докт. социол. н., проф., чл.-корр. НАН РК З.К. Шаукенова; д. филол. н., проф., чл.-корр. НАН РК А. Дербисали; доктор политических наук, проф., Бижанов А.К.; доктор ист. наук, проф., Кабульдинов 3.Е.; доктор филол. н., проф., член-корр. НАН РК Қажыбек Е.3.

$$
\text { Р е дакци онны й со в е т }
$$

академик НАН Республики Молдова Г. Белостечник (Молдова); академик НАН Азербайджанской Республики Н. Велиханлы (Азербайджан); академик НАН Республики Таджикистан Т.Н. Назаров (Таджикистан); академик НАН Республики Молдова А. Рошка (Молдова); академик НАН Республики Молдова Г. Руснак (Молдова); чл.-корр. НАН Азербайджанской Республики Ш. Мурадов (Азербайджан), член-корр. НАН Азербайджанской Республики 3.Сафарова (Азербайджан); д. э. н., проф. В.Н. Василенко (Украина); д.ю.н., проф. В.А. Устименко (Украина)

Известия Национальной академии наук Республики Казахстан. Серия общественных и гумани-тарных наук.

ISSN 2224-5294

Собственник: РОО «Национальная академия наук Республики Казахстан» (г. Алматы)

Свидетельство о постановке на учет периодического печатного издания в Комитете информации и архивов Министерства культуры и информации Республики Казахстан № 10894-Ж, выданное 30.04.2010 г.

Периодичность 6 раз в год

Тираж: 500 экземпляров

Адрес редакции: 050010, г. Алматы, ул. Шевченко, 28; ком. 219, 220; тел. 272-13-19, 272-13-18

http://soc-human.kz/index.php/en/arhiv 
Chief Editor

Honorary member of NAS RK

Balykbayev T.O

Editorial board:

Doctor of economics, prof, academician of NAS RK Baimuratov U.B.; doctor of philosophy, prof, academician of NAS RK Esim G.E.; doctor of philology, prof, academician of NAS RK Kirabayev S.S.; doctor of economics, prof, academician of NAS RK Koshanov A.K.; doctor of economics, prof, academician of NAS RK Naribayev K.N. (deputy editor-in-chief); doctor of philosophy, prof, academician of NAS RK Nyssanbayev A.N.; doctor of law, prof, academician of NAS RK Sabikenov S.N.; doctor of law, prof, academician of NAS RK Suleymenov M.K.; doctor of economy, prof, academician of NAS RK Satybaldin S.S.; doctor of history, prof, academician of NAS RK Abzhanov H.M; doctor of history, prof, corresponding member of NAS RK Abuseitova M.H.; doctor of history, prof, academician of NAS RK Baitanaev B.A.; doctor of philology, prof, corresponding member of NAS RK Zhakyp B.A.; doctor of philology, prof, academician of NAS RK Kalizhanov U.K.; doctor of philology, prof, academician of NAS RK Hamzabekuly D.; doctor of history, prof, academician of NAS RK Kozhamzharova D.P.; doctor of history, prof, academician of NAS RK Koigeldiev M.K.; doctor of philology, prof, corresponding member of NAS RK Kurmanbaiuly Sh.; doctor of history, prof, academician of NAS RK Taimaganbetov J.K.; doctor of sociology, prof, corresponding member of NAS RK Shaukenova Z.K.; doctor of philology, prof, corresponding member of NAS RK Derbisali A.; doctor of political science, prof Bizhanov A.K; doctor of History, prof Kabuldinov Z.E.; doctor of philology, prof, corresponding member of NAS RK Kazhybek E.Z.

\section{Editorial staff:}

Academician NAS Republic of Moldova Belostechnik.G (Moldova); Academician NAS Republic of Azerbaijan Velikhanli N. (Azerbaijan); Academician NAS Republic of Tajikistan Nazarov T.N. (Tajikistan); Academician NAS Republic of Moldova Roshka A. (Moldova) Academician NAS Republic of Moldova Rusnak G. (Moldova); Corresponding member of the NAS Republic of Azerbaijan Muradov Sh. (Azerbaijan); Corresponding member of the NAS Republic of Azerbaijan Safarova Z. (Azerbaijan); Associate professor of Economics Vasilenko V.N. (Ukraine), Associate professor of Law Ustimenko V.A. (Ukraine)

News of the National Academy of Sciences of the Republic of Kazakhstan. Series of Social and Humanities. ISSN 2224-5294

Owner: RPA "National Academy of Sciences of the Republic of Kazakhstan" (Almaty)

The certificate of registration of a periodic printed publication in the Committee of information and archives of the Ministry of culture and information of the Republic of Kazakhstan N 10894-Ж, issued 30.04.2010

Periodicity: 6 times a year

Circulation: 500 copies

Editorial address: 28, Shevchenko str., of. 219, 220, Almaty, 050010, tel. 272-13-19, 272-13-18

http://soc-human.kz/index.php/en/arhiv

(C) National Academy of Sciences of the Republic of Kazakhstan, 2020

Address of printing house: «NurNaz GRACE», 103, Ryskulov str, Almaty. 
N E W S

OF THE NATIONAL ACADEMY OF SCIENCES OF THE REPUBLIC OF KAZAKHSTAN

SERIES OF SOCIAL AND HUMAN SCIENCES

ISSN 2224-5294

https://doi.org/10.32014/2020.2224-5294.32

Volume 2, Number 330 (2020), 19 - 24

\author{
A. Sayken, Zh. Akimov \\ L.N. Gumilyov Eurasian National University, \\ Astana, Republic of Kazakhstan. \\ E-mail: adai_seken@mail.ru, akimov_zhm@enu.kz

\section{MAIN DIRECTIONS OF DEVELOPMENT OF KAZAKH NATIONAL CULTURAL TOURISM}

\begin{abstract}
The modern Kazakh nation has been formed with the participation of many tribes and peoples for centuries. It is one of the oldest ethnic groups that plays an important role in the history of Eurasia. The Kazakh people inherited the culture of all ethnic groups who had contributed to the formation of the Kazakh nation, and therefore, Kazakhstan is valued as a nation with a rich cultural heritage. This article examines the theories and practices of national ethnographic tourism development on the example of Kazakh culture. The principal directions of the development of Kazakh national ethnographic cultural tourism and ways of their implementation are presented by taking into account the world experience of national ethnic cultural tourism. At the same time, based on the experience of foreign countries and considering the potential of Kazakhstan, the main directions of the development of national ethnographic cultural tourism were presented. In this article, the authors identified the Kazakh ethnographic historical and cultural resources and presented the ways to implement them.
\end{abstract}

Key words: Kazakh national culture, resource, ethno tourism, development, direction, cultural tourism, ethnographic culture, model.

\title{
INTRODUCTION
}

A national ethnographic tourism is a cultural tourism of high level. It is also one of the main contents of tourism discoveries and tourist activities that satisfy the spiritual needs of tourists along with gaining new knowledge about nations and nationalities and discovering new countries and lands. According to the study of International Tourism Organizations, only $26 \%$ of tourists traveling abroad were interested in indigenous landmarks and ancient cities, while $56.7 \%$ were interested in acquaintance with the national ethnographic culture and traditions of the local people. Therefore, nowadays developed and developing countries consider the development of national ethnographic tourism as the main direction of tourism.

For instance, in North America, the Living History Museum designed an "immigrants' village" which reflects conventional houses of American immigrants who moved to the North America centuries ago and stone and wooden houses of native Americans from the ancient times. These installations recall their lifestyle, traditions and customs of American people. Tunisia enhanced tourism industry through developing national ethnographic tourism. Based on the interests and requirements of western travelers it promoted the indigenous lifestyle of Berbers and their living places, national garments and production tools which assisted it to become one of the country with developed tourism industry among African and Arab countries.

A national ethnographic village of 25 nations constructed in Yunnan Province of China and a national ethnographic village of 56 nationalities constructed in Shenzhen, China, the world-famous electronics industry centre, turned popular tourist destinations that attract tourists from around the world and hugely contributing to the budget of country. Therefore, nowadays the discovery and study of national ethnographic culture tourism became a vital subject.

\section{THEORETICAL RESEARCH}

The main directions of national ethnographic culture tourism development based on international experience are divided into several groups as seen below: 
The national ethnographic tourism

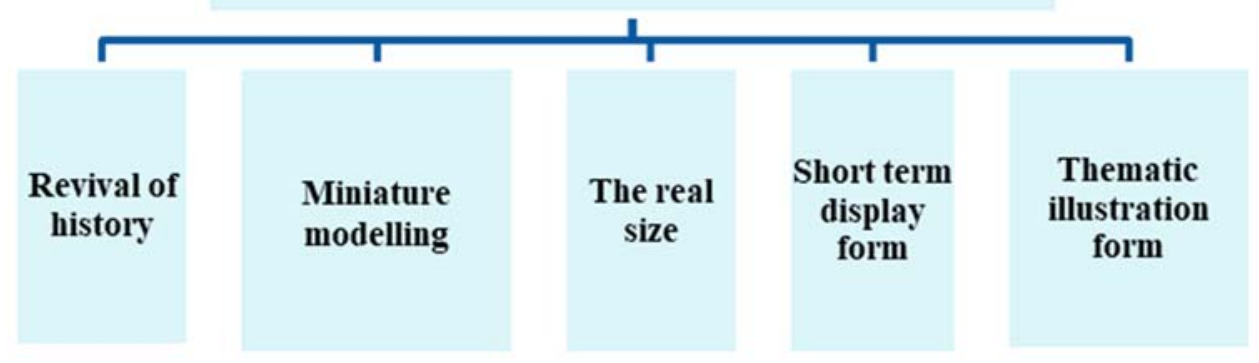

Graph 1 - The main models of national ethnographic and cultural tourism

1. The revival of history. The aim of this model is to collect, edit, group and extract forgotten or destroyed national ethnographic cultural resources based on historical data and to explain the ancient ethnographic culture of the indigenous peoples and nationalities lived in this region to tourists.

For example, the Living History Museum in the USA attracts the tourists with scenic employeesactors or actors dressed up in national garments of American immigrants of the XVI-XVII centuries, who plow the farmland, carry the things with one-wheel cart, carry the water and perform national dances and sing songs. The advantage of this model is to plunge the tourist's imagination into the past by 'moving the time backwards'.

2. Miniature modelling. Nowadays, the resources of the national ethnographic culture are neglected due to external civilizations impact, changing lifestyle of people and fast-paced time.

For example, architectural art, garment models, tradition of the people are losing the former characteristic due to globalization process. As some activities in the national ethnographic culture are only reflected in a specific timeframe (for example, during holidays and celebrations), many foreign tourists will not be able to fully understand the national ethnographic culture and traditions of the local people due to seasonal barriers. In order to overcome them, local governments and investors should choose an appropriate geographical area, analyse the national ethnographic tradition, and build a thematic garden (miniature model) based on the traditions and customs of the local population and national ethnographic resources. This model can provide a decent amount information to tourists relatively in a short timeframe. These two different models can be converted into one type, namely, the museum form.

3. The real size. This form is designed to show tourists notable national ethnographic cultural resources through a typical analysis of prominent, accessible regions. The content is mainly based on the representation of the natural production of ethnographic tradition in rural settlements. This is mainly aimed to attract tourists who are interested in virgin nature and who don't seek for any modern life conveniences. For example, Maoli wintering in the Hawaiian Islands. The peculiarity of this model is that with a small investments tourists can closely interact with the local people and enjoy the nature, take part in their every-day lives and production activities, which give them a deep satisfaction and feeling of appreciation.

4. Short term display form. This model is available in two different ways. The first type is practiced during the national holidays. For example, Nauryz, Kurban Eid, Ramadan and others. The second type (form) is mobile visualization of portable national ethnographic cultural arts. For example, performance of national ethnographic orchestras abroad. This form enables the foreign nationalities to enjoy, feel, and comprehend with the help of national ethnographic culture and arts.

5. Thematic illustration form. Attraction of tourists through integration of tourism and a specific branch of national ethnographic culture content of one nation. For example, theme park, thematic hotel etc. [1]. Opening national ethnographic tourism resources in one region should reflect national ethnographic culture in line with the true local situation of the region. In terms of regional development, national ethnographic tourism resources are the most competitive areas in the development of regional tourism. 
A substantial requirement for the discovery of national ethnographic tourism resources is a set of traditions of material, spiritual and public governance of nations and nationalities, which are the main national ethnographic culture, national traditions and customs.

This includes the following contents: industrial household traditions, national arts, sports traditions, folklore art, beliefs and superstitions and public social traditions [2, p. 18]. The national ethnographic content must be carefully selected. The principle of this selection is an attractiveness of national ethnographic content. Tourist attractiveness is the national ethnographic difference between the local region and the region where the tourist market is planned. As the national ethnographic culture of the local region is particularly striking, the difference gets more great and more attractive. Therefore, the focus on the content is more in priority.

The Kazakh national ethnographic culture is rich and has infinite renewal nature. For example, architectural buildings, national cuisine, Kazakh military civilization, mausoleums reflecting the belief system and religion, the cluster of historical tribes illustrating the national heritage of Kazakhs, resettlement culture of Kazakhs (river civilization), cluster of Khans, national arts, national holidays and celebrations $[3$, p. 46].

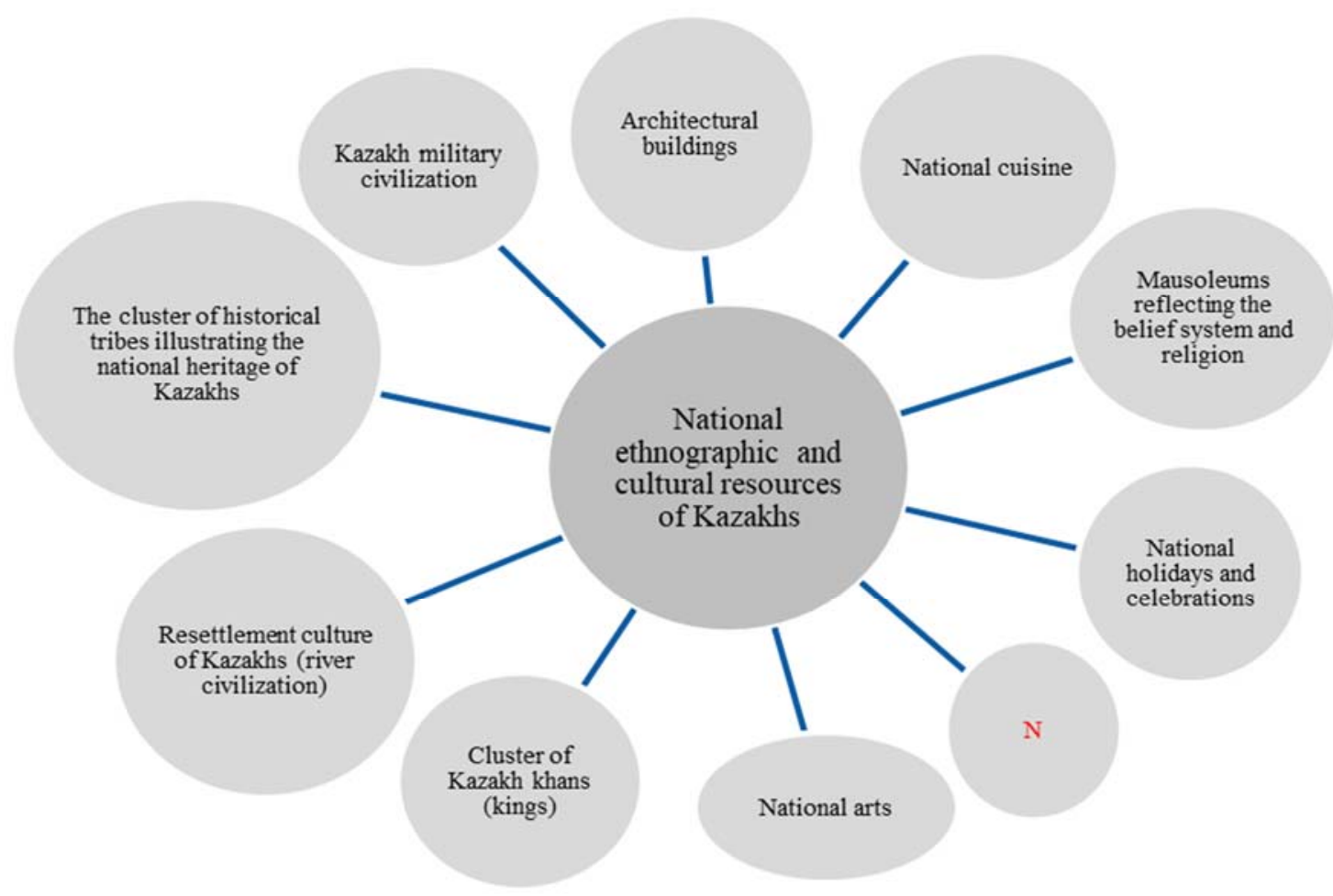

Graph 2 - National ethnographic and cultural resources of Kazakhs

Based on the resources of the Kazakh national ethnographic culture and world experience, the main directions of the development of national ethnographic tourism in Kazakhstan can be classified as follows:

1. The art of architecture, especially a famous Kazakh yurt, which represents nomadic culture in Kazakh architecture. Kazakh yurt with twenty-five thousand years old history has no equivalent in the world and is very comfortable for household and production utilization and climate challenges. The Kazakh type yurt is one of the best yurt forms. Its structure and every piece of it is a testimony of philosophy, science, mathematics, art, and religious beliefs. The foreign tourists find it astounding and unique.

2. Ancient cities representing resettlement civilization (river civilization) of Kazakhs: Otyrar, Sauran, Syganakh, Taraz, Saraishykh etc.

3. Mausoleums representing the belief system and religion: Khoja Akhmet Yassawi, Arystan Bab, Aisha Bibi, Balbals, Carved boulders etc.

4. Kazakh military civilization. Weapons, warriors, mausoleums of warriors 
5. Restored clusters of historical tribes, reflecting the Kazakh national ancestry. For example, Sakas, Hun, Uisyn, Kangly, Sarmat, Botay cultures etc.

6. Cluster of Kazakh khans. Zhuz (tribal division), rhu (clans) etc.

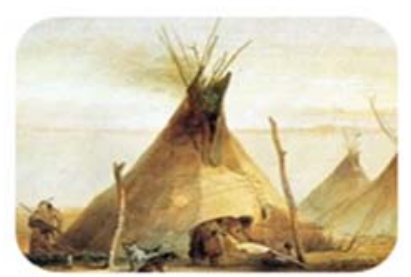

1) Tipi. (American Indian Tents)[4].

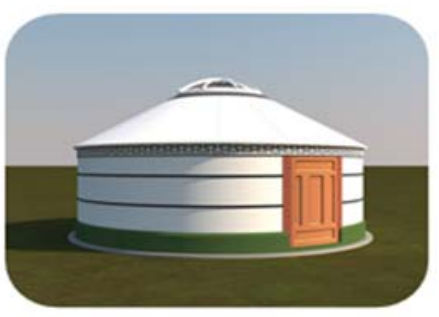

4) Mongol yurt [7].

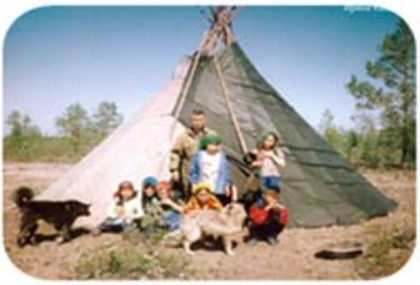

2) Chum. (A tent of Nothern Siberian Nomads )[5].

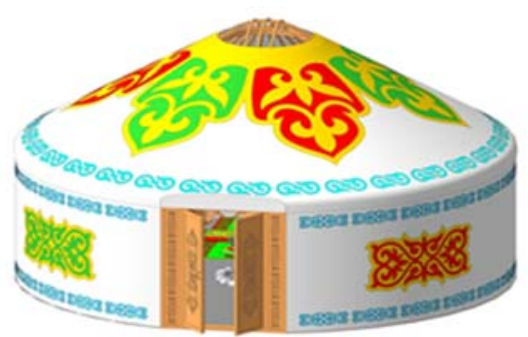

5) Kazakh yurt [8].

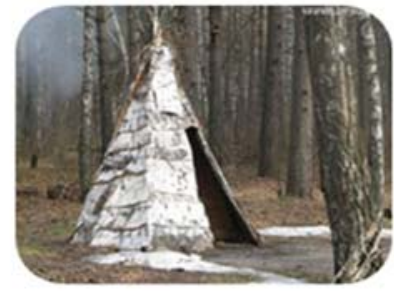

3) Odag. (A tent of Southern- East Siberian Peoples)[6].

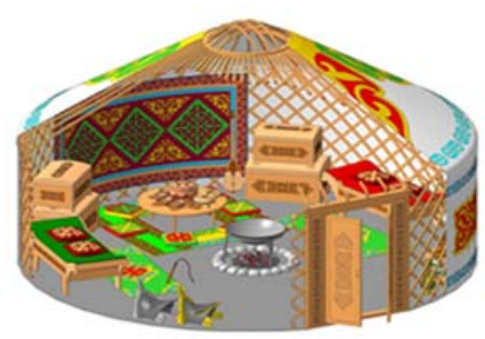

6) Interior of Kazakh yurt [9].

Graph 3 - Houses of various nationalities and Kazakh yurt

7. National art. National musical instruments and arts (aitys, kui, terme, arnau, syngsu, hormonica playing, singing, khobyz etc.) and national dances (karazhorga, kamajai etc.)[10].

8. National cuisine. Beshbarmak, kuyrdak, bauyrsak, kazy-karta, kurt, butter, yoghurt, kymyz, shubat etc.

9. National holidays and celebrations. Nauryz, Eid celebrations, Korisu eid and others.

\section{The ways of implementation:}

1. For the implementation of national ethnographic tourism objects, integration with the major tourist routes should be undertaken, i.e. to complement tourism types such as ecotourism, sports tourism, urban tourism, etc. with one another by formulating one tourism route.

2. Adaptation of national ethnographic tourism to the tourism market. This market is represented in three different ways. The first type is foreign tourists, who are interested in Kazakh national ethnographic culture. The second group is ethnic Kazakhs in foreign countries. Their goal is to explore their cultural heritage and business opportunities. The third group is local Kazakh citizens. Their aims are continuum of tradition, patriotism, to inform the younger generation of their history and national culture.

3. In the course of the discovery, it is important to promote advertising and formation of tourism brand, namely, to combine ethnic ethnographic culture, rural life and landscape. In creation of tourism brand a promotion of tourism through show business, cinema, soap operas can be practiced. For example, shooting films such as "The Way to the Mother" and "The Home ".

\section{CONCLUSION}

Nowadays, each country considers tourism as a successful means of economic development. Therefore, because of the change in the leisure style and the choice of tourists, many countries are focusing on creating new routes along with the traditional marketplace of tourism. Through a number of practices, the development of national ethnographic tourism is a proven new source of income. Tourism development is based on resource opportunities. 
The potential of Development of national ethnographic and cultural tourism in Kazakhstan is also very high. The history, national culture, customs and traditions of our culture are very rich and have special features and competitive advantages. By developing this direction of tourism, we develop not only tourism in the country but also contribute to the development of the overall regional economy. At the same time, the world should recognize our country not only by our energy resources but know better our history, national identity, traditions, customs and culture. From this point of view, one of the most important directions of the tourism industry in Kazakhstan is considered a development of national ethnographic cultural tourism.

\title{
А. Секен, Ж.М. Акимов
}

\author{
Л.Н. Гумилев атындағы Еуразия ұлттық университеті, \\ Астана, Қазақстан
}

\section{ҚАЗАКТЫН ҰЛТТЫК МӘДЕНИЕТ ТУРИЗМІН ДАМЫТУДЫН БАСТЫ БАҒЫТТАРЫ}

Аннотация. Мақалада Қазақстанның ұлттық этнографиялық мәдени туризмі саласын зерттеу нәтижелері талқыланады. Қазіргі таңда әр ел туризм саласын экономиканы дамытудың табысты көзі ретінде қарастырып келеді. Өйткені демалыс стилі мен туристердің саяхаттау талғамында өзгерістер пайда болуына байланысты, көптеген елдер туризмнің дәстүрлі нарық жүйесін сақтаумен қатар, жаңа бағыттарды ашуға да көңіл бөліп отыр. Зерттеулерге сүйене отырып және бірқатар тәжірибелер арқылы ұлттық этнографиялық туризмді дамыту - туризмнің жаңа бір табыс көзі екені дәлелденді. Туризмді дамыту ресурстық мүмкіндіктерді қажет етеді. Қазақстанның да ұлттық этнографиялық мәдени туризмін дамыту потенциялы өте жоғары. Халқымыздың тарихы, ұлттық мәдениеті, салт-дәстүрі, әдет-ғұрпы өте бай және ерекше тартымдылыққа ие. Қазақтың ұлттық этнографиялық мәдениет ресурстары - өте бай, үздіксіз туындап отыратын шексіз мәнге ие құрылым. Қазақ халқы көптеген тайпалар мен халықтардың қатысуымен ғасырлар бойы қалыптасқан. Еуразия тарихында маңызды орын алатын ең көне этностардың бірі болып саналады. Қазақ халқы - қазақ ұлтының қалыптасуына ықпал еткен барлық халықтардың мәдениетінің мұрагері, сондықтан қазақ халқының ұлттық мәдениеті аса бай мәдениеттердің бірі болып саналады. Бұл мақалада қазақтың ұлттық этнографиялық мәдениетін мысалға ала отырып, ұлттық этнографиялық туризмді дамытудың теориялары мен тәжірибелері жөнінде зерттеулер жүргізіледі.

Мақалада ұлттық этникалық мәдени туризмнің әлемдік тәжірибелерін мысалға ала отырып, қазақтың ұлттық этнографиялық мәдени туризмін дамытудың басты бағыттары және оларды іске асыру жолдары ұсынылады. Сонымен қатар шетелдердегі тәжірибелерді негізге ала отырып және Қазақстанның әлеуетін ескере отырып, ұлттық этнографиялық мәдени туризмді дамытудың негізгі бағыттары ұсынылған. Қазақтық ұлттық этнографиялық тарихи және мәдени ресурстары айқындалып, оларды іске асыру жолдары ұсынылған.

Түйін сөздер: қазақ ұлттық мәдениеті, ресурс, этно туризм, даму, бағыт, мәдени туризм, этнографиялық мәдениет, модель.

\section{А. Секен, Ж.М. Акимов}

Евразийский национальный университет имени Л.Н. Гумилева, Астана, Казахстан

\section{ОСНОВНЫЕ НАПРАВЛЕНИЯ РАЗВИТИЯ КАЗАХСКОГО НАЦИОНАЛЬНОГО КУЛЬТУРНОГО ТУРИЗМА}

Аннотация. В статье обсуждаются результаты исследований в области национального этнографического культурного туризма в Казахстане. В настоящее время каждая страна рассматривает индустрию туризма как успешный источник экономического развития. Из-за изменения стиля отдыха и туристических предпочтений туристов многие страны концентрируются на открытии новых направлений, сохраняя при этом традиционную систему туристического рынка. На основании исследований и благодаря 
ряду практик, развитие национального этнографического туризма стало новым источником туризма. Развитие туризма требует ресурсных возможностей. Казахстан также имеет большой потенциал для развития национального этнографического культурного туризма. История, национальная культура, обычаи и традиции нашего народа очень богаты и имеют особую привлекательность. Структура казахской национальной этнографической культуры очень богата и имеет бесконечную структуру. Казахская нация, прошедшая долгий период формирования, в процессе которого принимало участие множество племен и народов, занимает важное место в истории Евразии и является одним из древнейших этносов. Она является преемницей культурного наследия всех народов, принявших участие в ее становлении, поэтому казахский народ - один из богатейших народов в культурном плане.

В этой статье также рассматриваются теории и практика развития национального этногра-фического туризма с учетом национальной этнографической культуры этнических Казахов. Принимая во внимание мировой опыт развития национального этнического культурного туризма, будут представлены основные направления развития казахстанского национального этнографического культурного туризма и пути их реализации. А также предложены основные направления развития национального этнографического культурного туризма, основанные на опыте зарубежных стран и с учетом потенциала Казахстана. Определены исторические и национальные этнографические культурные ресурсы, а также представлены способы их реализации.

Ключевые слова: казахская национальная культура, ресурс, этно туризм, развитие, направление, культурный туризм, этнографическая культура, модель.

Information about authors:

Sayken Adai - L.N. Gumilyov Eurasian National University, Department of tourism, Astana, the Republic of Kazakhstan, E-mail: adai_seken@mail.ru https://orcid.org/0000-0003-0790-7222;

Akimov Zhaxylyk Makmutovich - L.N. Gumilyov Eurasian National University, doctoral student 3st year of the department "Tourism", Astana, the Republic of Kazakhstan, E-mail: akimov_zhm@enu.kz, https://orcid.org/0000-0002-5476-9742.

\section{REFERENCES}

[1] Adai Seken, Yan Chaupin, Shui Shaolyan. «Study of modeling of the development of the Kazakh national cultural tourism». Altai State Agrarian University: 2011. - 09 (p. 83).

[2] Akseleu Seidimbek. «The history of Kazakh culture». Astana, 2008. p.18.

[3] Erengayip Omarov. «Kazakh civilization». Beijing, 2008. p. 46.

[4] Wall newspaper «Briefly and clearly about the most interesting». Issue No. 88, Dwelling of the World [E-Resource]. 2016. URL: http://xn----stb8d.xn--plai/wp-content/gallery/88/47.jpg (access date: 02.02.2016).

[5] Wall newspaper "Briefly and clearly about the most interesting". Issue No. 88, Dwelling of the World [E-Resource]. 2016. URL: http://xn----stb8d.xn--p1ai/wp-content/gallery/88/58.jpg (access date: 2.02.2016).

[6] Wall newspaper "Briefly and clearly about the most interesting". Issue No. 88, Dwelling of the World [E-Resource]. 2016. URL: http://xn----stb8d.xn--p1ai/wp-content/gallery/88/36.jpg (access date: 02.02.2016).

[7] Mongol yurt 3D modelling - 3D graphics [e-resource]. 2015. URL: https://freelance.ru/HaltarJonon/?work=2214130 (access date: 11.02.2015).

[8] XI competition of Computer aces in 3D modelling, Project of Pavlodar petrochemical plant LLP [e-resource]. 2013. URL: https://ascon.ru/news_and_events/news/1599/\#gallery-40 (access date: 19.09.2013).

[9] XI competition of Computer aces in 3D modelling, Project of Pavlodar petrochemical plant LLP [e-resource]. 2013. URL: https://ascon.ru/news_and_events/news/1599/\#gallery-37 (access date: 19.09.2013).

[10] Adayi Saiken, Yang Zhaoping, Mazbayev O.B., Duisembaev A.A., Izembayev B.ZH., Nasanbayeva S.T. "Ethnic cultural tourism resources evaluation development: Kazak cultural tourism resources analysis" Journal of Environmental Management and Tourism, 2017i-V.8. Iss.2. P.467-475, Germany. 


\title{
PUBLICATION ETHICS AND PUBLICATION MALPRACTICE IN THE JOURNALS OF THE NATIONAL ACADEMY OF SCIENCES OF THE REPUBLIC OF KAZAKHSTAN
}

For information on Ethics in publishing and Ethical guidelines for journal publication see http://www.elsevier.com/publishingethics and http://www.elsevier.com/journal-authors/ethics.

Submission of an article to the National Academy of Sciences of the Republic of Kazakhstan implies that the work described has not been published previously (except in the form of an abstract or as part of a published lecture or academic thesis or as an electronic preprint, see http://www.elsevier.com/postingpolicy), that it is not under consideration for publication elsewhere, that its publication is approved by all authors and tacitly or explicitly by the responsible authorities where the work was carried out, and that, if accepted, it will not be published elsewhere in the same form, in English or in any other language, including electronically without the written consent of the copyrightholder. In particular, translations into English of papers already published in another language are not accepted.

No other forms of scientific misconduct are allowed, such as plagiarism, falsification, fraudulent data, incorrect interpretation of other works, incorrect citations, etc. The National Academy of Sciences of the Republic of Kazakhstan follows the Code of Conduct of the Committee on Publication Ethics (COPE), and follows the COPE Flowcharts for Resolving Cases of Suspected Misconduct (http://publicationethics.org/files/u2/New_Code.pdf). To verify originality, your article may be checked by the originality detection service Cross Check http://www.elsevier.com/editors/plagdetect.

The authors are obliged to participate in peer review process and be ready to provide corrections, clarifications, retractions and apologies when needed. All authors of a paper should have significantly contributed to the research.

The reviewers should provide objective judgments and should point out relevant published works which are not yet cited. Reviewed articles should be treated confidentially. The reviewers will be chosen in such a way that there is no conflict of interests with respect to the research, the authors and/or the research funders.

The editors have complete responsibility and authority to reject or accept a paper, and they will only accept a paper when reasonably certain. They will preserve anonymity of reviewers and promote publication of corrections, clarifications, retractions and apologies when needed. The acceptance of a paper automatically implies the copyright transfer to the National Academy of sciences of the Republic of Kazakhstan.

The Editorial Board of the National Academy of sciences of the Republic of Kazakhstan will monitor and safeguard publishing ethics.

Правила оформления статьи для публикации в журнале смотреть на сайте:

\author{
www:nauka-nanrk.kz \\ http://soc-human.kz/index.php/en/arhiv \\ Редакторы: М. С. Ахметова, Г. Б. Халидуллаева, Д. С. Аленов \\ Верстка на компьютере А.М. Кульгинбаевой \\ Подписано в печать 19.03..2020 \\ Формат 60x881/8. Бумага офсетная. Печать - ризограф. \\ 14 п.л. Тираж 500. Заказ 2.
}

Национальная академия наук $Р К$

050010, Алматы, ул. Шевченко, 28, т. 272-13-18, 272-13-19 